\title{
BOWEN'S DISEASE OF THE BREAST: A RARE ENTITY
}

M. Valluvan¹, P. Viswanathan², P. V. S. Prasad ${ }^{3}$, P. K. Kaviarasan', L. Lakshmana Rao ${ }^{5}$

\section{HOW TO CITE THIS ARTICLE:}

M. Valluvan, P. Viswanathan, P. V. S. Prasad, P. K. Kaviarasan, L. Lakshmana Rao. "Bowen's Disease of the Breast: A Rare Entity". Journal of Evolution of Medical and Dental Sciences 2014; Vol. 3, Issue 22, June 02; Page: 6048-6052, DOI: $10.14260 /$ jemds/2014/2703

ABSTRACT: OBJECTIVE: To present a case of Bowen's disease of the breast. CASE REPORT: A 51 years old female presented to the dermatology out-patient department with large plaque measuring $15 \times 13 \mathrm{cms}$ on her right breast, of twenty years evolution. A clinical diagnosis of Bowen's disease/Paget's disease/Lupus vulgaris of the breast was made. Histopathological examination confirmed Bowen's disease. CONCLUSION: In the present case, Bowen's disease extensively involved the breast along with complete destruction of nipple and areola and rarity of occurrence over sunprotected area like breast and without history suggestive of arsenic exposure. There was no associated underlying carcinoma of the breast or internal malignancies. Histo-pathologically Paget's disease and lupus vulgaris was ruled out and a final diagnosis of Bowen's disease was made. Hence we publish this case for its rarity.

KEYWORDS: Bowen's disease, Breast, carcinoma in-situ.

INTRODUCTION: Bowen's disease was first described by an American Dermatologist John T. Bowen in the year 1912.1 Bowen's disease is a form of carcinoma in situ of the skin with full-thickness involvement of the epidermis, with etiologic factors such as ultraviolet exposure, arsenic exposure and human papilloma virus.

Bowen's disease usually presents as a clearly defined erythematous papular plaque and most frequently occurs on sun-exposed sites.2,3 Rarely Bowen's disease also can occur in non-sun exposed sites, which suggest a history of arsenic exposure ${ }^{4}$ with possible association of internal visceral malignancy. 5, 6, 7 Ulceration of the Bowen's is suggestive of invasive carcinoma. ${ }^{8}$

The possible sources of arsenic vary in different localities. Agricultural workers may be exposed to arsenic salts used as a fungicide, weed killer, sheep dip or pesticide, and they frequently take inadequate precautions against accidental ingestion or inhalation. It may be a hazard in smelting and other industrial processes.

Bowen's disease manifests itself as a slowly enlarging erythematous patch of sharp but irregular outline, showing little or no infiltration. Within the patch are generally areas of scaling and crusting. ${ }^{9}$

Paget's disease an intraepidermal neoplasms that may occasionally pose a problem in differential diagnosis, especially when they occur on the breast.2,10,11 Paget disease is the name given to a crusted lesion of the nipple caused by breast carcinoma, as originally described by Sir James Paget in $1874 .{ }^{12}$ Clinically, Paget's disease appears weeping, eczema-like lesions are centered in the nipple. Later they may involve the areola and surrounding epidermis, but they rarely extend more than a few centimeters. If a definite mass can be palpated beneath the diseased nipple, the underlying tumor will have an invasive component in over $90 \%$ of cases. ${ }^{13}$

The distinction between Paget's disease and Bowen's disease is important, because of the differences in treatment and associated diseases. ${ }^{2,3,11}$ 
CASE REPORT: A 51 year old female presented with a single large asymptomatic gradually progressive large plaque, with ulceration, scaling, crusting, and measuring $15 \mathrm{x} 13 \mathrm{cms}$ in the right breast of 20 years duration. The healed area showed atrophic scarring. The lesion started as a small ulcer and had been treated intermittently but without any improvement attained the present size and it is not tender. There was complete destruction of the nipple and areola of the right breast with no underlying palpable mass. A small nodule of size $10 \times 7 \mathrm{~mm}$ seen over the right infra-mammary region. No history of bloody discharge from the nipple. She was married for 30 years and surviving with two children's. No regional lymphadenopathy. Systemic examination and blood investigations appeared normal and other breast was clinically normal. Ultrasonography and MRI of abdomen was normal. X ray and CT chest was normal. Mammogram did not reveal any mass on both the breasts. Electron microscopy studies was not performed due to the lack of facility.

Clinical diagnosis of Bowen's disease/Paget's disease/Lupus vulgaris was made. Biopsy was taken and submitted for Histopathological examination.

HISTOPATHOLOGICAL EXAMINATION: Stratified squamous epithelium shows markedly dysplastic cells with marked pleomorphism. Bi nucleated cells and tri polar mitotic figures are seen. Vacuolated cells characteristic of Paget's disease (Pagetoid cells) are not seen. Surface of the epithelium covered with purulent exudate.

DISCUSSION: Bowen's disease consists of a solitary lesion and occurs on both Photo exposed and unexposed areas. Exposure to arsenic and human Papilloma virus can predispose to occurrence over sun-protected areas, with possible association of internal malignancy. Two studies disagree with this opinion. ${ }^{14,15}$ Only a few cases of Bowen's disease of breast had been reported worldwide. ${ }^{16-19}$

In the present case a 51 year-old women presented with a solitary plaque like lesion with scaling and crusting over the right breast for the past 20 years. The lesion had been gradually increased in size over the years. The patient did not have any exposure to arsenic and no internal malignancy was identified. In the present case, considering the size of the lesion and PAS stain was negative for Paget cells, the possibility of Paget's disease was ruled out. Diascopy was negative, histopathology did not revealed granuloma and hence Lupus vulgaris was ruled out. A diagnosis of Bowen's disease was made.

In Histopathological examination, arsenical Bowen's disease is said to be characterized by the presence of numerous vacuolated atypical cells. ${ }^{20,21}$ In Paget's disease, microscopically large clear cells with atypical nuclei are seen within the epidermis, usually concentrated along the basal layer but also permeating the Malpighian layer. The cells can be isolated or in clusters, and sometimes they form small glandular structures. ${ }^{22}$ In Bowen's disease, but not in Paget's disease, clumping of nuclei within multinucleated epidermal cells will be seen. ${ }^{23}$

In the present case, Histopathological examination showed features of Bowen's disease.

CONCLUSION: In the present case, Bowen's disease occurred in an unexposed area without any history of arsenic exposure and internal malignancy, which in breast is a rare entity. Paget's disease and Lupus vulgaris was ruled out and a final diagnosis of Bowen's disease was made. 


\section{EQUIPMENT USED:}

Nikon Coolpix-8400

$\mathrm{x}$-denotes the power of objective

Stain used - (H \& E)

\section{REFERENCES:}

1. Walter F. Lever, Histopathology of the skin. $7^{\text {th }}$ edition.1990; chapter 26: 551.

2. Callen P Headington. Bowen's and non- Bowen's squamous intraepidermal neoplasia of the skin. Arch Dermatol. 1980; 1 16:422-426.

3. Graham JH, Mazanti GR, Helwig EB. Chemistry of Bowen's disease: Relationship to arsenic. J Invest Dermatol.1961; 37:317-332.

4. Peterka ES, Yncb FW, Coltz RW. An association between Bowen's disease and internal cancer. Arch Dermatol. 1961; 84:623-629.

5. Graham JH, Helwig EB. Bowen's disease and its relationship to systemic cancer. Arch Dermatol. 1959; 80:133 - 59.

6. Hugo NE, Conway H. Bowen's disease: Its malignant potential and relationship to systemic cancer. Plast Reconstr Surg.1967; 39:190-194.

7. Graham JH. Selected precancerous skin and mucocutaneous lesions. In: Fitzpatrick TB, Eisen AZ, Wolff K, et al., eds. Neoplasms of Skin and Malignant Melanoma. Chicago: Year Book, 1976: 69.

8. Schwartz RA, Stoll HL Jr. Epithelial precancerous lesions. In: Fitzpatrick TB, Eisen AZ, Wolff K, et al., eds. Fitzpatrick's Dermatology in General Medicine, 5th edn. New York: McGraw-Hill, 1999: 832-834.

9. Walter F. Lever, Histopathology of the skin. $9^{\text {th }}$ edition.2005; chapter 29: 826.

10. Fisher ER, Breyer FR. Differentiation of neoplastic lesions characterized by large vacuolated intraepidermal (pagetoid) cells. Arch Pathol. 1959:67:140-145.

11. Ashikari R, Park D, Huvos AC, et al. Paget's disease of the breast. Cancer, 1970; 26:f.80 685.

12. Paget J. On disease of the mammary areola preceding cancer of the mammary gland. St Barth Hosp Rep 1874; 10:87-89.

13. Ashikari R, Park K, Huvos AG, Urban JA. Paget's disease of the breast. Cancer 1970; 26:680-685.

14. Bernstein SC, Lim KK, Brodland DG, Heildelberg KA. The many faces of squamous cell carcinoma. Dermatol Surg 1996; 22:243-254.

15. Preston DS, Stern RS. Nonmelanoma cancers of the skin. N Eng J Med 1990; 327:1649-1662.

16. Blobstein SH, Wolfin NS, Urmacher C, Myskowski PL. Pagetoid Bowen's disease of the breast. Int J Dermatol 1986; 25:381-382.

17. Venkataseshan VS, Budd DC, Kim DU, Hutter VP. Intraepidermal squamous carcinoma (Bowen's disease) of the nipple. Hum Pathol 1994; 25:1371-1374.

18. Ortiz-Mendoza CM, Acosta-Sánchez NA, Catarino-Dircio A. Bowen's disease of the breast. Cir Cir. 2005 Sep-Oct; 73(5):379-81.

19. Duperrat B, Carton FX. Bowen's disease of the breast. Bull Soc Fr Dermatol Syphiligr. 1969; 76(6):764-5.

20. Seiji M, Mizuno F. Electron microscopic study of Bowen's disease. Arch Dermatol 1969; 99: 316. 


\section{CASE REPORT}

21. Yeh S, Chen HC, How SW et al. Fine structure of Bowen's disease in chronic arsenicalism. J Natl Cancer Inst1975; 53: 31-3.

22. Shousha S. Glandular Paget's disease of the nipple. Histopathology 2007; 50:812-814.

23. Walter F. Lever, Histopathology of the skin. 9th edition.2005; chapter 29: 853.

\section{MACROSCOPIC-PICTURE:}

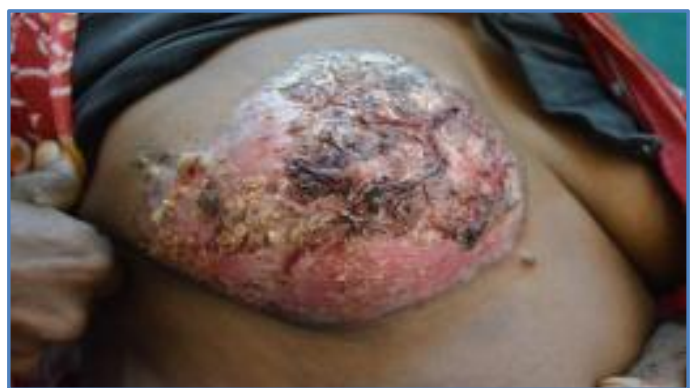

Fig. 1: Lesion showing ulceration, scaling and crusting

\section{MICROSCOPIC PICTURES:}

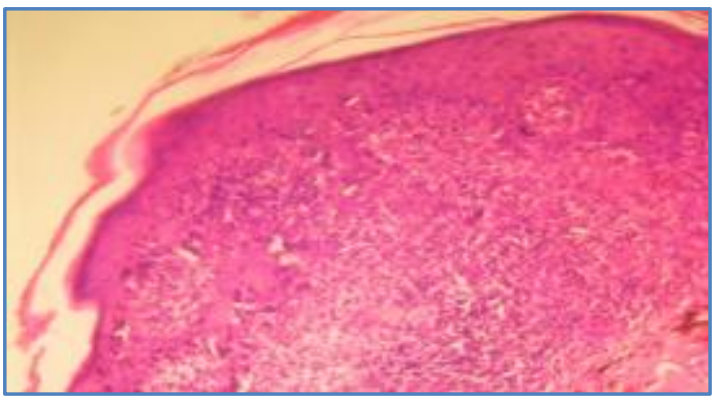

Fig. 2: Disorderedand dysplastic epithelial cells and Binuleated cells. (H \& E) stained x4

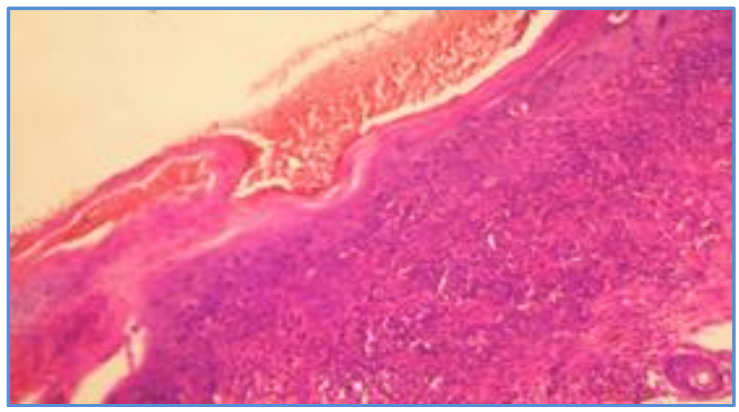

Fig. 3: Showing Loss of polarity and marked nuclear pleomorphism of epithelial cells, multinucleated cells.(H\&E) stained $x 4$ 


\section{CASE REPORT}

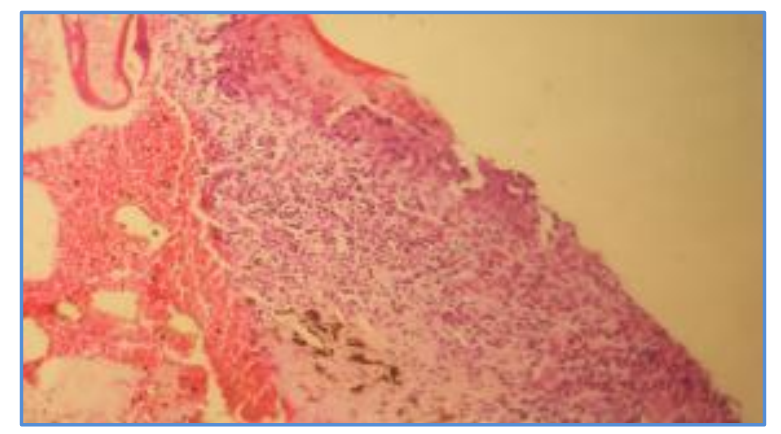

Fig. 4: Showing partially ulcerated epithelium and purulent exudate. (H \& E) stained X10

\section{AUTHORS:}

1. M. Valluvan

2. P. Viswanathan

3. P. V. S. Prasad

4. P. K. Kaviarasan

5. L. Lakshmana Rao

\section{PARTICULARS OF CONTRIBUTORS:}

1. $2^{\text {nd }}$ Year Post Graduate, Department of Pathology, Rajah Muthiah Medical College, Annamalai University.

2. Professor, Department of Pathology, Rajah Muthiah Medical College, Annamalai University.

3. Professor, Department of Dermatology Venereology and Leprosy, Rajah Muthiah Medical College, Annamalai University.

4. Professor, Department of Dermatology Venereology and Leprosy, Rajah Muthiah Medical College, Annamalai University.
5. Professor, Department of Pathology, Rajah Muthiah Medical College, Annamalai University.

\section{NAME ADDRESS EMAIL ID OF THE CORRESPONDING AUTHOR:}

Dr. P. Viswanathan,

Professor, Department of Pathology,

Faculty of Medicine,

Rajah Muthiah Medical College, Annamalai University, Chidambaram, Tamilnadu, India, PIN - 608002.

Email: drviswanathan2013@gmail.com

Date of Submission: 15/05/2014. Date of Peer Review: 16/05/2014. Date of Acceptance: 24/05/2014. Date of Publishing: 30/05/2014. 